DOI 10.21685/2500-0578-2020-4-4

\title{
OVERWINTERING AND NEW RECORDS OF INVASIVE HARLEQUIN LADYBIRD HARMONIA AXYRIDIS (PALLAS, 1773) (COLEOPTERA: COCCINELLIDAE) AFTER MASS EXPANSION TO EUROPEAN PART OF RUSSIA IN 2018-2019
}

\author{
A. S. Sazhnev', V. V. Anikin', V. V. Zolotukhin ${ }^{3}$ \\ Severtsov Institute of Ecology and Evolution, 33 Leninsky prosp., Moscow, 117071, Russia \\ E-mail: sazh@list.ru \\ ${ }^{2}$ Chernyshevsky Saratov State University, 83 Astrakhanskaya street, Saratov, 410012, Russia \\ E-mail: anikinvasiliiv@mail.ru \\ ${ }^{3}$ Ulyanovsk State Pedagogical University, 4 Lenin square, Ulyanovsk, 432701, Russia \\ E-mail:v.zolot@mail.ru
}

${ }^{1}$ Papanin Institute for Biology of Inland Waters Russian Academy of Sciences, 101 Borok, Yaroslavl region, 152742, Russia;

Abstract. The data on the first record of harlequin ladybird (Harmonia axyridis) in Ryazan, Tula, Tver, Oryol, Orenburg regions and the Udmurt Republic are presented. On the studied parts of invasive distribution area of $H$. axyridis, the development of two generations is recorded. $H$. axyridis winters during imaginal diapause, gathering in large groups. The date of the migratory flight varies from early September to mid-October. Many bugs die of starvation during the postwintering period. Overwintering specimens of Harmonia axyridis (after mass expansion to European part of Russia in 2018-2019) were recorded in many regions in 2020: Kursk, Penza, Samara, Saratov, Volgograd, Astrakhan regionns, the Republic of Mordovia, Tatarstan and Chuvash Republic.

Key words: Harmonia axyridis, harlequin ladybird, multicolored Asian ladybird, invasive species, fauna, new records.

Acknowledgements. We are grateful to Ju. V. Volkova (Ulyanovsk, Russia) and O. V. Sinichkina (Saratov, Russia) for providing specimens of Harmonia axyridis. The research of A. S. Sazhnev was funded by the Russian Science Foundation, Project No 16-14-10031.

For citation: Sazhnev A.S., Anikin V.V., Zolotukhin V.V. Overwintering and new records of invasive harlequin ladybird Harmonia axyridis (pallas, 1773) (coleoptera: coccinellidae) after mass expansion to European part of Russia in 2018-2019. Russian Journal of Ecosystem Ecology. 2020;5(4). Available from: https://doi.org/10.21685/2500-05782020-4-4

УДК 581.524.2 (595.763.79)

\section{ЗИМОВКА И НОВЫЕ НАХОАКИ ИНВАЗИОННОЙ КОРОВКИ HARMONIA AXYRIDIS (PALLAS, 1773) (COLEOPTERA, COCCINELLIDAE) ПОСЛЕ МАССОВОЙ ЭКСПАНСИИ НА ТЕРРИТОРИИ ЕВРОПЕЙСКОЙ ЧАСТИ РОССИИ В 2018-2019 ГОААХ}

\author{
А. С. Сажнев', В. В. Аникин ${ }^{2}$ В. В. Золотухин ${ }^{3}$ \\ ${ }^{1}$ Институт биологии внутренних вод им. И. Д. Папанина Российской академии наук, \\ Россия, 152742, Ярославская обл., Борок, 101; \\ Институт проблем экологии и эволюции им. А. Н. Северцова Российской академии наук, \\ Россия, 117071, г. Москва, Ленинский проспект, 33 \\ E-mail: sazh@list.ru \\ ${ }^{2}$ Саратовский государственный университет им. Н. Г. Чернышевского, Россия, 410012, г. Саратов, ул. Астраханская, 83 \\ E-mail: anikinvasiliiv@mail.ru \\ 3 Ульяновский государственный педагогический университет, Россия, 432701, г. Ульяновск, пл. Ленина, 4 \\ E-mail:v.zolot@mail.ru
}


Аннотация. Впервые данные по азиатской божьей коровке (Harmonia axyridis) приводятся для Рязанской, Тульской, Тверской, Орловской, Оренбургской областей и территории Республики Удмуртия. На исследованных участках инвазионного ареала Н. axyridis зарегистрировано развитие двух поколений. В период имагинальной диапаузы Н. axyridis зимуют, собираясь большими группами. Сроки перелета на зимовку варьируют от начала сентября до середины октября. Многие жуки погибают от голода после зимовки. Перезимовавшие (после массовой экспансии в Европейской части России в 2018-2019 гг.) oсоби Harmonia axyridis отмечены в 2020 г. для Курской, Пензенской, Самарской, Саратовской, Волгоградской, Астраханской областей, а также Республики Мордовия, Татарстана и Чувашии.

Ключевые слова: Harmonia axyridis, азиатская божья коровка, божья коровка-арлекин, инвазионный вид, фауна, новые находки.

\section{Introduction}

The harlequin ladybird Harmonia axyridis (Pallas, 1773) is one of the most rapidly spreading beetle species, its range is increasing at a rate of 100 $500 \mathrm{~km}$ per year [1]. The original area of $H$. axyridis is Asia including particular districts of the Oriental Region [2,3], where distribution of this species is restricted by tropical climates. The most northwestern finding native point of $H$. axyridis is Tyukalinsk, Omsk oblast [3]. The Asian (initial) distribution area of this species is continuous and comprises a wide variety of ecological conditions [3]. In the last 25 years H. axyridis has established in Europe, North America, South America, and Africa [1]. In European part of Russia this ladybird was firstly recorded in the 2004 year in Belgorod oblast [4], and now it is widely distributed through the European Russia, where it is known from Kaliningrad, Belgorod, Lipetsk, Moscow, Bryansk, Voronezh and Rostovon-Don oblasts, Krasnodar and Stavropol Kray, Adygea, Dagestan, Kabardino-Balkaria, North Ossetia, Crimea and Bashkir Republics [5-14]. The mass reproduction of Harmonia axyridis (Pallas, 1773) (Coleoptera: Coccinellidae) was recorded in many Russian regions (Republics of Tatarstan and Mordovia, Chuvash Republic, Nizhny Novgorod, Pskov, Kursk, Tambov, Penza, Ulyanovsk, Samara, Saratov, Volgograd, Astrakhan oblasts and the Chechen Republic) in 2018-2019 [15-17]. Monitoring an invasive species remains relevant, and the opportunity of the species (as Harmonia axyridis) to assimilate and gain a foothold in a new territory requires a detailed study. This determined the purpose of this research.

\section{Material and methods}

The material has been collected by authors and colleagues during investigation of the complex expedition in 2020 year. Specimens of $H$. axyridis were collected using UV-light trap and manual collecting. The part of the observations was made thanks to the online project www.inaturalist.org. Names of morphs are given according to Andrianov et al. [18]. Total over 1000 specimens of $H$. axyridis have been examined (2018-2020).

Map was created in SimpleMappr online service (www.simplemappr.net).

\section{Results and discussion}

Harmonia axyridis (Pallas, 1773)

Material examined. Orenburg oblast: Ilek distr., Ilek vill., 10.10.2019, 1 ex. (f. succinea), unknown collector. Oryol oblast: Oryol, 8.10.2018, 2 exs. (f. succinea), unknown collector. Ryazan oblast: Rayzan distr., Murmino vill., 7.05.2020, 1 ex. (f. spectabilis), unknown collector; Rayzan, 11.05.2020, 1 ex. (f. succinea), unknown collector. Saratov oblast: Khvalynsk distr., Khvalynsk, facility of Saratov State University, $52.4861^{\circ} \mathrm{N}$, $48.0439^{\circ} \mathrm{E}, \mathrm{UV}$-light, 23-27.06.2020, 7 exs. (5 f. succinea, 1 - f. conspicua, 1 - f. spectabilis), V. V. Anikin leg.; Saratovsky district, Raslovka-2 vill., $51.7777^{\circ} \mathrm{N}, 46.2339^{\circ} \mathrm{E}$, holiday village, in the garden, at day, 28.06.2020, 2 exs. (f. succinea), O. V. Sinichkina leg.; Saratov, B. Sadovaya str., $51.5217^{\circ} \mathrm{N}, 45.9837^{\circ} \mathrm{E}$, apartment, on the UVlight, 6-13.08.2019, 1 ex. (f. succinea), V.V. Anikin leg.; same locality, on the UV-light, 20.08.2019, 2 exs. (f. succinea), V. V. Anikin leg.; same locality, on the UV-light, 20-25.08.2019, 12 exs. (10 - f. succinea, 2 - f. spectabilis $)$, V. V. Anikin leg.; same locality, on the UV-light, 27.08.2019, 5 exs. (f. succinea), V. V. Anikin leg.; Novouzensk distr., Novouzensk, 23.08.2020, 1 ex. (f. succinea), unknown collector. Tula oblast: Shekino distr., Shekino vill., 3.05.2020, 1 ex. (f. succinea), unknown collector. Tver oblast: Konakovo, 5.10.2020, 1 ex. (f. succinea) N. Larionov leg.; Udmurt Republic: Glazov distr., Glazov, 24.09.2019, 1 ex. (f. spectabilis), unknown collector.

It is the first records of harlequin ladybird for Tula, Tver, Rayzan, Oryol, Orenburg oblasts and the Udmurt Republic (Fig. 1). 


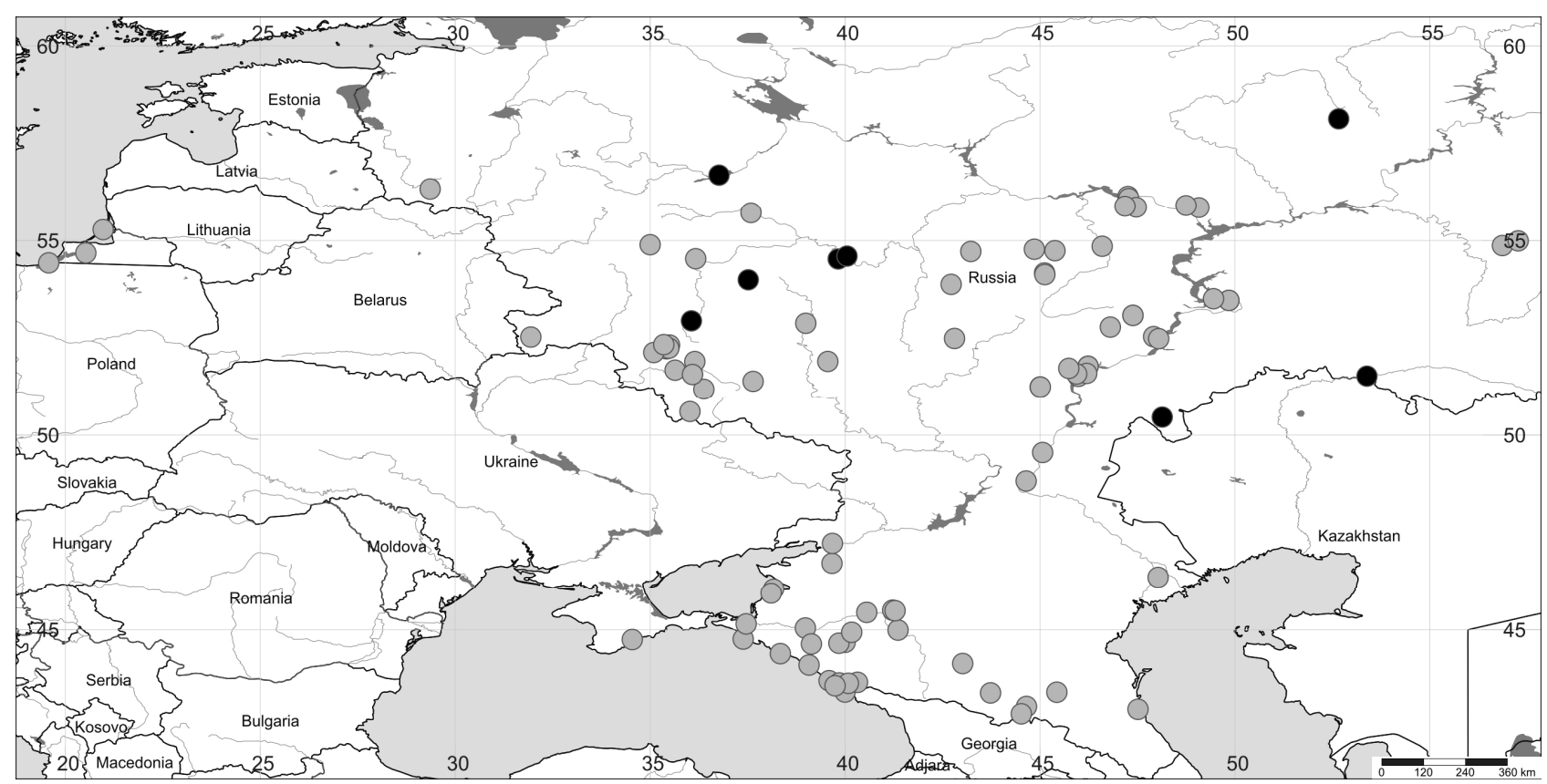

Fig. 1. Records of Harmonia axyridis from European Russia: gray circles - literature data, black circles - new records

One to four generations of $H$. axyridis develop during an active season, depending on the duration of the warm period [3], on the studied parts of areas recorded two generations develop (as on the biggest part of the area).

H. axyridis winters during imaginal diapause, gathering in large groups in cracks at southern slopes of mounds and hills, as well as in houses, within a major part of both the native and invasive distribution area $[3,19,20]$, this is also observed in the studied populations. Overwintering specimens of Harmonia axyridis were recorded in many regions of European part of Russia in 2020: Kursk, Penza, Samara, Saratov, Volgograd, Astrakhan oblasts, the Republic of Mordovia, Tatarstan and Chuvash Republic [17, and orig.]. The date of the migratory flight varies from early September to mid-October, and depends on climatic conditions $[3,21]$.
Postwintering migration occurs as the temperature rises in late February to early May, depending on climatic conditions [3,20]. Many beetles die of starvation during this period, when humidity is low and food is absent [3]. On the territory of the national park «Khvalynsky», where in the fall of 2019 there was a mass outbreak of the species [15], the species overwintered, but «lost» most of the adults who went to winter. The number of dead adults in shelters (forest floor, clumps of trees, attics, etc.) to the number of survivors was at the end of May - mid-June 2020 as 1:500-600!

Harmonia axyridis is a very polymorphic species with variations in the coloration pattern within a fairly broad range [22, 23]. It has long been an object of geneticists' study [1, 3, 23-25]. New records (2020) in European part of Russia presented two coloration form: f. succinea and f. spectabilis (Fig. 2).
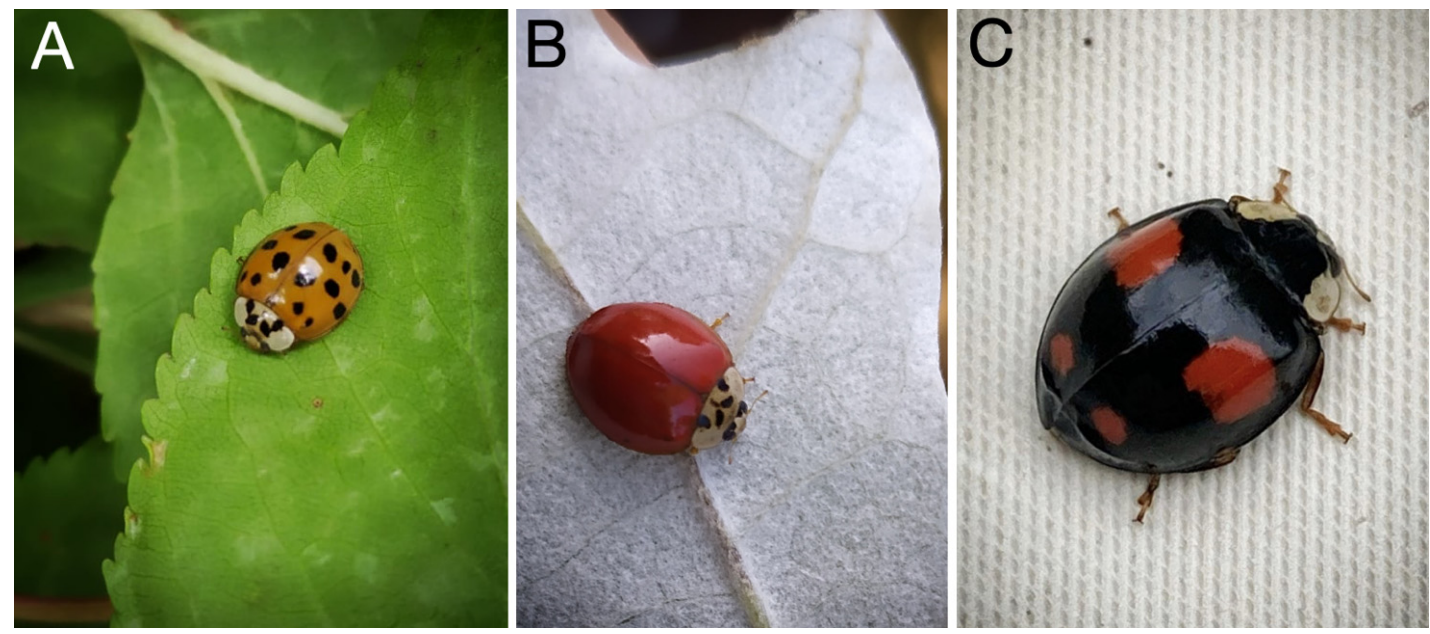

Fig. 2. Coloration form of Harmonia axyridis from Saratov oblast: A-B - f. succinea; $C$ - f. spectabilis. Photo by O. V. Sinichkina 
Apparently, the settlement of the European part of Russia is a spontaneous expansion of the species range both from the West, which is confirmed by the findings of $H$. axyridis f. axyridis in the Kursk oblast [17], and from the south of Russia, where the «strong point» represented by local populations of H. axyridis introduced to the Caucasus [12] plays a significant role in the colonization of the species (primarily in the Volga region) [10].

A similar rapid penetration along the Volga River line is known for other invasive species, for example horse-chestnut leaf miner - Cameraria ohridella Deschka \& Dimić, 1986 [26] or emerald ash borer Agrilus planipennis Fairmaire, 1888 [27].

\section{Conclusion}

The species Harmonia axyridis once again expresses itself as a dangerous and aggressive invader. In a single year, this invasive harlequin ladybird spreaded itself more than $500 \mathrm{~km}$ along the Volga River to the north. In our opinion, in the future we should expect the closure of the native (from Kazakhstan) and the adventive ranges of $H$. axyridis.

On the studied parts of invasive distribution area of $H$. axyridis recorded, two generations develop. $H$. axyridis winters during imaginal diapause, gathering in large groups in cracks of buildings (more often), at southern slopes of mounds, less often in between stones, under bark and in leaf litter. The date of the migratory flight varies from early September to mid-October. Many beetles die of starvation during postwintering period (the number of dead adult specimens to the number of survivors is $1: 500-600)$.

\section{Библиографический список}

1. The global spread of Harmonia axyridis: distribution, dispersal and routes of invasion / P. M. J. Brown, C. Thomas, E. Lombaert, D. L. Jeffries, A. Estoup, L. J. Lawson Handley // BioControl. - 2011. - № 56 (4). - P. 623-642.

2. Catalogue of Palearctic Coleoptera / ed. by I. Lobl, A. Smetana. - Stenstrup : Apollo Books, 2007. - Vol. 4. - 935 p.

3. Blekhman, A. V. Native area and biological features of invasive ladybird Harmonia axyridis / A. V. Blekhman, I. I. Goryacheva // Biology Bulletin Reviews. - 2017. - Vol. 7. - P. 103-112.

4. Binkovskaya, O. V. The role of forest shelter belts in the protection of Coccinellids as biological pest control agents on agricultural crops / O. V. Binkovskaya // Ecological problems of agricultural production : Proceedings of the international scientific-practical conference. - Voronezh : Edit House of Voronezh Agr. Univ., 2004. - P. 117-118.

5. Alekseev, V. I. Contributions to the knowledge of beetles (Insecta: Coleoptera) in the Kaliningrad region / V. I. Alekseev, A. Bukejs, M. Balalaikins // Zoology and Ecology. - 2012. - Vol. 22. - P. 99-110.

6. Emets, V. M. Finds of ladybird Harmonia axyridis (Coleoptera, Coccinellidae) in Voronezhsky Reserve (Voronezhskaya Oblast of Russia) / V. M. Emets // Russ. J. Biol. Invasions. - 2018. - Vol. 1. - P. 33-37.

7. Khabibullin, A.F. On the fauna of Coccinellidae (Coleoptera) of the nothern (industrial) part of Ufa city / A. F. Khabibullin, I. I. Safina, V. F. Khabibullin // Vestnik Mordovia Univ. Ser. Biol. Sci. - 2009. - Vol. 1. P. 74.

8. Korotyaev, B. A. On high abundance of the Harlequin lady beetle, Harmonia axyridis (Pall.) (Coleoptera, Coccinellidae), in the plains of the Northwestern Caucasus, Russia / B. A. Korotyaev // Entomological Review. 2015. - № 95 (9). - P. 1317-1319.

9. Kruglova, O. Yu. Registration of invasive ladybird beetle Harmonia axyridis Pallas (Coleoptera, Coccinellidae) in Bryansk region / O. Yu. Kruglova, A. S. Roginsky, A. V. Sinchuk // Proceedings of the Belarusian State University. 2015. - № 10 (1). - P. 389-391.

10. Orlova-Bienkowskaja, M. Ja. The dangerous invasive harlequin ladybird Harmonia axyridis (Pallas, 1773) (Coleoptera, Coccinellidae) in European Russia / M. Ja. Orlova-Bienkowskaja // Russ. J. Biol. Invasions. - 2013. Vol. 1. - P. 75-82.

11. Orlova-Bienkowskaja, M. Ja. The first record of Asian ladybird Harmonia axyridis (Pallas, 1773) (Coleoptera: Coccinellidae) in Kabardino-Balkaria and the history of the expansion of this alien species in the Caucasus and south of European Russia in 2002-2015 / M. Ja. Orlova-Bienkowskaja, T. A. Mogilevich // Caucasian Entomological Bulletin. - 2016. - Vol. 12, № 1. - P. 93-98.

12. Украинский, А. С. Азиатская божья коровка Harmonia axyridis Pall. (Coleoptera, Coccinellidae) на Северном Кавказе / А. С. Украинский // Евразиатский энтомологический журнал. - 2013. - Т. 12, № 1. - С. 35-38.

13. Ukrainsky, A. S. Expansion of Harmonia axyridis Pallas (Coleoptera: Coccinellidae) to European Russia and adjacent regions / A. S. Ukrainsky, M. Ja. Orlova-Bienkowskaja // Biological Invasions. - 2014. - Vol. 16, № 5. P. 1003-1008.

14. Жесткокрылые насекомые (Insecta, Coleoptera) Республики Адыгея (аннотированный каталог видов) / под ред. А. С. Замотайлова, Н. Б. Никитского. - Майкоп : Изд-во Адыгейского государственного университета, 2010. - 404 с. - (Конспекты фауны Адыгеи. № 1).

15. Аникин, В. В. Насекомые инвайдеры в Поволжье в XXI веке / В. В. Аникин // Природа Симбирского Поволжья. - 2019. - Вып. 20. - С. 92-97. 
16. Егоров, Л. В. Harmonia axyridis (Pallas, 1773) (Coleoptera: Coccinellidae) - новый чужеродный вид в фауне Поволжья / Л. В. Егоров, В. Н. Подшивалина, Н. В. Борисова, А. Б. Ручин // Eversmannia. - 2019. - Т. 5960. - C. 73 .

17. Expansion of Harmonia axyridis (Pallas, 1773) (Coleoptera: Coccinellidae) to European part of Russia in 2018 2020 / A. B. Ruchin, L. V. Egorov, E. A. Lobachev, S. V. Lukiyanov, A. S. Sazhnev, G. B. Semishin // Baltic J. Coleopterol. - № 20 (1). - P. 51-60.

18. Asian ladybug Harmonia axyridis: a global invasion / B. V. Andrianov, A. V. Blechman, I. I. Goryacheva, I. A. Zakharov-Gezekhus, D. A. Romanov. - Moscow : KMK Scientific Press Ltd., 2018. - 143 p.

19. Koch, R. L. The multicoloured Asian lady beetle, Harmonia axyridis: a review of its biology, uses in biologicalcontrol and non-target impacts / R. L. Koch // Journal of Insect Science. - 2003. - Vol. 32, № 3. - P. 1-16.

20. Voronin, K. E. Specific development of wintering Far Eastern population of Harmonia axyridis - Far Eastern predator of aphids / K. E. Voronin // Tr. Vses. Nauchno-Issled. Inst. Zashch. Rast. - 1965. - № 24. - P. $223-228$.

21. LaMana, M. L. Field observations on Harmonia axyridis (Coleoptera: Coccinellidae) / M. L. LaMana, J. C. Miller // Biological Control. - 1996. - Vol. 6. - P. 232-237.

22. Blekhman, A. V. Variability of the pronotum pattern of ladybird Harmonia axyridis Pallas (Coleoptera, Coccinellidae) / A. V. Blekhman // Ecological Genetics. - 2007. - Vol. 5, № 2. - P. 25-36.

23. Blekhman, A. V. Population variation of elytral ridge occurrence in ladybirds Harmonia axyridis Pallas / A. V. Blekhman // Russian Journal of Genetics. - 2008. - Vol. 44, № 11. - P. 1351-1354.

24. Zakharov, I. A. Mitochondrial DNA polymorphism in invasive and native populations of Harmonia axyridis / I. A. Zakharov, I. I. Goryacheva, A. Suvorov // European Journal of Environmental Sciences. - 2011. - Vol. 1. P. 15-18.

25. Blekhman, A. V. Differentiation of Harmonia axyridis Pall. according to polymorphic morphological traits and variability of the mitochondrial COI gene / A. V. Blekhman, I. I. Goryacheva, I. A. Zakharov // Moscow Univ. Biol. Sci. Bull. - 2010. - Vol. 65, № 4. - P. 174.

26. Anikin, V. V. Present day bio-invasions in the Volga-Ural Region: from the South to the North or from the East to the West? Cameraria ohridella (Lepidoptera: Gracillariidae) in the Lower and Middle Volga / V. V. Anikin // Zootaxa. - 2019. - № 4624 (4). - P. 583-588.

27. Current range of Agrilus planipennis Fairmaire, an alien pest of ash trees, in European Russia and Ukraine / M. Ja. Orlova-Bienkowskaja, A. N. Drogvalenko, I. A. Zabaluev, A. S. Sazhnev, E. Yu. Peregudova, S. G. Mazurov, E. V. Komarov, V. V. Struchaev, V. V. Martynov, T. V. Nikulina, A. O. Bieńkowski // Annals of Forest Science. 2020. - № 77 (2). - P. 1-29.

\section{References}

1. Brown P. M. J., Thomas C., Lombaert E., Jeffries D. L., Estoup A., L. J. Lawson Handley BioControl. 2011, no. 56 (4), pp. 623-642.

2. Catalogue of Palearctic Coleoptera. Ed. by I. Lobl, A. Smetana. Stenstrup: Apollo Books, 2007, vol. 4, 935 p.

3. Blekhman A. V., Goryacheva I. I. Biology Bulletin Reviews. 2017, vol. 7, pp. 103-112.

4. Binkovskaya O. V. Ecological problems of agricultural production: Proceedings of the international scientificpractical conference. Voronezh: Edit House of Voronezh Agr. Univ., 2004, pp. 117-118.

5. Alekseev V. I., Bukejs A., Balalaikins M. Zoology and Ecology. 2012, vol. 22, pp. 99-110.

6. $\quad$ Emets V. M. Russ. J. Biol. Invasions. 2018, vol. 1, pp. 33-37.

7. Khabibullin A. F., Safina I. I., Khabibullin V. F. Vestnik Mordovia Univ. Ser. Biol. Sci. [Bulletin of Mordovia University. Biological Series]. 2009, vol. 1, p. 74.

8. Korotyaev B. A. Entomological Review. 2015, no. 95 (9), pp. 1317-1319.

9. Kruglova O. Yu., Roginsky A. S., Sinchuk A. V. Proceedings of the Belarusian State University. 2015, no. 10 (1), pp. 389-391.

10. Orlova-Bienkowskaja M. Ja. Russ. J. Biol. Invasions. 2013, vol. 1, pp. 75-82.

11. Orlova-Bienkowskaja M. Ja., Mogilevich T. A. Caucasian Entomological Bulletin. 2016, vol. 12, no. 1, pp. 93-98.

12. Ukrainsky A. S. Evraziatskiy entomologicheskiy zhurnal [Euroasian Entomol. J.]. 2013, vol. 12, no. 1, pp. 35-38 [In Russian].

13. Ukrainsky A. S., Orlova-Bienkowskaja M. Ja. Biological Invasions. 2014, vol. 16, no. 5, pp. $1003-1008$.

14. Zhestkokrylye nasekomye (Insecta, Coleoptera) Respubliki Adygeya (annotirovannyy katalog vidov) [Coleopterous insects (Insecta, Coleoptera) of Republic of Adygheya (annotated catalogue of species)]. Ed. by A. S. Zamotajlov, N. B. Nikitsky. Maykop: Adyghei State Univ. Publ., 2010, 404 p. (Fauna conspecta of Adygheya 1). [In Russian].

15. Anikin V. V. Priroda Simbirskogo Povolzh'ya [The nature of the Simbirsk Volga Region]. 2019, no. 20, pp. 92-97. [In Russian].

16. Egorov L. V., Podshivalina V. N., Borisova N. V., Ruchin A. B. Eversmannia. 2019. Vol. 59-60, pp. 73. [In Russian].

17. Ruchin A. B., Egorov L. V., Lobachev E. A., Lukiyanov S. V., Sazhnev A. S., Semishin G. B. Baltic J. Coleopterol. No. 20 (1), pp. 51-60.

18. Andrianov B. V., Blechman A. V., Goryacheva I. I., Zakharov-Gezekhus I. A., Romanov D. A. Asian ladybug Harmonia axyridis: a global invasion. Moscow: KMK Scientific Press Ltd., 2018, 143 p. 
19. Koch R. L. Journal of Insect Science. 2003, vol. 32, no. 3, pp. 1-16.

20. Voronin K. E. Tr. Vses. Nauchno-Issled. Inst. Zashch. Rast. [Proceedings of All-Russian Research Institute for Plants Protection] 1965, no. 24, pp. 223-228.

21. LaMana M. L., Miller J. C. Biological Control. 1996, vol. 6, pp. 232-237.

22. Blekhman A. V. Ecological Genetics. 2007, vol. 5, no. 2, pp. 25-36.

23. Blekhman A. V. Russian Journal of Genetics. 2008, vol. 44, no. 11, pp. 1351-1354.

24. Zakharov I. A., Goryacheva I. I., Suvorov A. European Journal of Environmental Sciences. 2011, vol. 1, pp. 15-18.

25. Blekhman A. V., Goryacheva I. I., Zakharov I. A. Moscow Univ. Biol. Sci. Bull. 2010, vol. 65, no. 4, p. 174.

26. Anikin V. V. Zootaxa. 2019, no. 4624 (4), pp. 583-588.

27. Orlova-Bienkowskaja M. Ja., Drogvalenko A. N., Zabaluev I. A., Sazhnev A. S., Peregudova E. Yu., Mazurov S. G., Komarov E. V., Struchaev V. V., Martynov V. V., Nikulina T. V., Bieńkowski A. O. Annals of Forest Science. 2020, no. 77 (2), pp. 1-29. 